\title{
Water Quality Assessment of the Semenyih River, Selangor, Malaysia
}

\author{
Fawaz Al-Badaii, Mohammad Shuhaimi-Othman, and Muhd Barzani Gasim \\ School of Environmental and Natural Resource Sciences, Faculty of Science and Technology, Universiti Kebangsaan Malaysia (UKM), \\ 43600 Bangi, Selangor, Malaysia
}

Correspondence should be addressed to Fawaz Al-Badaii; fawaz1980@siswa.ukm.edu.my

Received 3 May 2013; Accepted 21 July 2013

Academic Editor: Dimosthenis L. Giokas

Copyright (C) 2013 Fawaz Al-Badaii et al. This is an open access article distributed under the Creative Commons Attribution License, which permits unrestricted use, distribution, and reproduction in any medium, provided the original work is properly cited.

This study was carried out to determine the Semenyih River water quality based on the physicochemical and biological parameters. The sampling was conducted in dry and rainy seasons during 2012. Water samples were collected from 8 stations along the river and analyzed using standard methods. The results showed that temperature, $\mathrm{pH}$, conductivity, $\mathrm{TDS}, \mathrm{SO}_{4}$, and $\mathrm{TH}$ were classified as class I, while DO, turbidity, and BOD were categorized under class II, and $\mathrm{NH}_{3}-\mathrm{N}$, TSS, COD, and OG were categorized as class III based on NWQS, Malaysia. Moreover, $\mathrm{NO}_{3}$ was classified under class IV, while $\mathrm{PO}_{4}$ and $\mathrm{FC}$ were categorized as class $\mathrm{V}$ and exceeded the allowable threshold levels. Therefore, the river was slightly polluted with $\mathrm{NH}_{3}-\mathrm{N}$, TSS, $\mathrm{COD}$, and $\mathrm{NO}_{3}$, whereas it is extremely contaminated with $\mathrm{PO}_{4}$ and FC. Furthermore, cluster analysis classified 8 sampling stations into three clusters based on similarities of water quality features. Furthermore, factor analysis of the water quality datasets generated three factors with total variance of $94.05 \%$ and pointed out that water quality deterioration in the river was associated with industrial and agricultural activities, livestock farming, and erosion. Therefore, the river water can be used for irrigation with precaution but extensive treatment needed before using for domestic purposes.

\section{Introduction}

Water is an essential requirement of human life and activities associated with industry, agriculture, and others, and it considers one of the most delicate parts of the environment [1]. In the last few decades, the accelerated pace of industrial development and progressive growth of population caused in tremendous increase in the demand of fresh water [2]. The quality of surface and groundwater is identified in terms of its physical, chemical, and biological parameters [3]. The water quality of rivers is characterized by a high level of heterogeneity in time and space, because of the distinction of cover-land around. This often creates difficulties to identify water conditions and pollution sources, which is necessary to control effectively pollution in addition to construct successful strategies for minimizing of contamination resources [4]. Anthropogenic pollutants related to land use result in drastic deterioration of aquatic systems in watersheds [5]. Additionally, the rivers play an important role in assimilating municipal and industrial effluent as well as runoff from agricultural land and the surrounding area in a watershed [6]. On the other hand, rivers comprise the most important water resources for irrigation, domestic water supply, industrial, and other purposes in a watershed, thereby tending to stimulate serious hygienic and ecological problems. Consequently, prevention and controlling of river pollution and reliable evaluation of water quality are an imperative stipulation for effective management [7].

According to [8], human activities in particular husbandry livestock and agriculture play an important role in contributing contamination of river water among others pollutants. Wastewater of livestock contains high concentrations of ammonia nitrogen, organic and inorganic nitrogen compound, and pathogenic bacteria [9]. Furthermore, serious environmental damage as a result of animal waste has been well documented in rivers which receive runoff of nutrient rich waste that caused oxygen depletion and increased the algae production [10].

Study of surface water pollution of the river is important due to effluents from municipal sewage, livestock wastewater, 

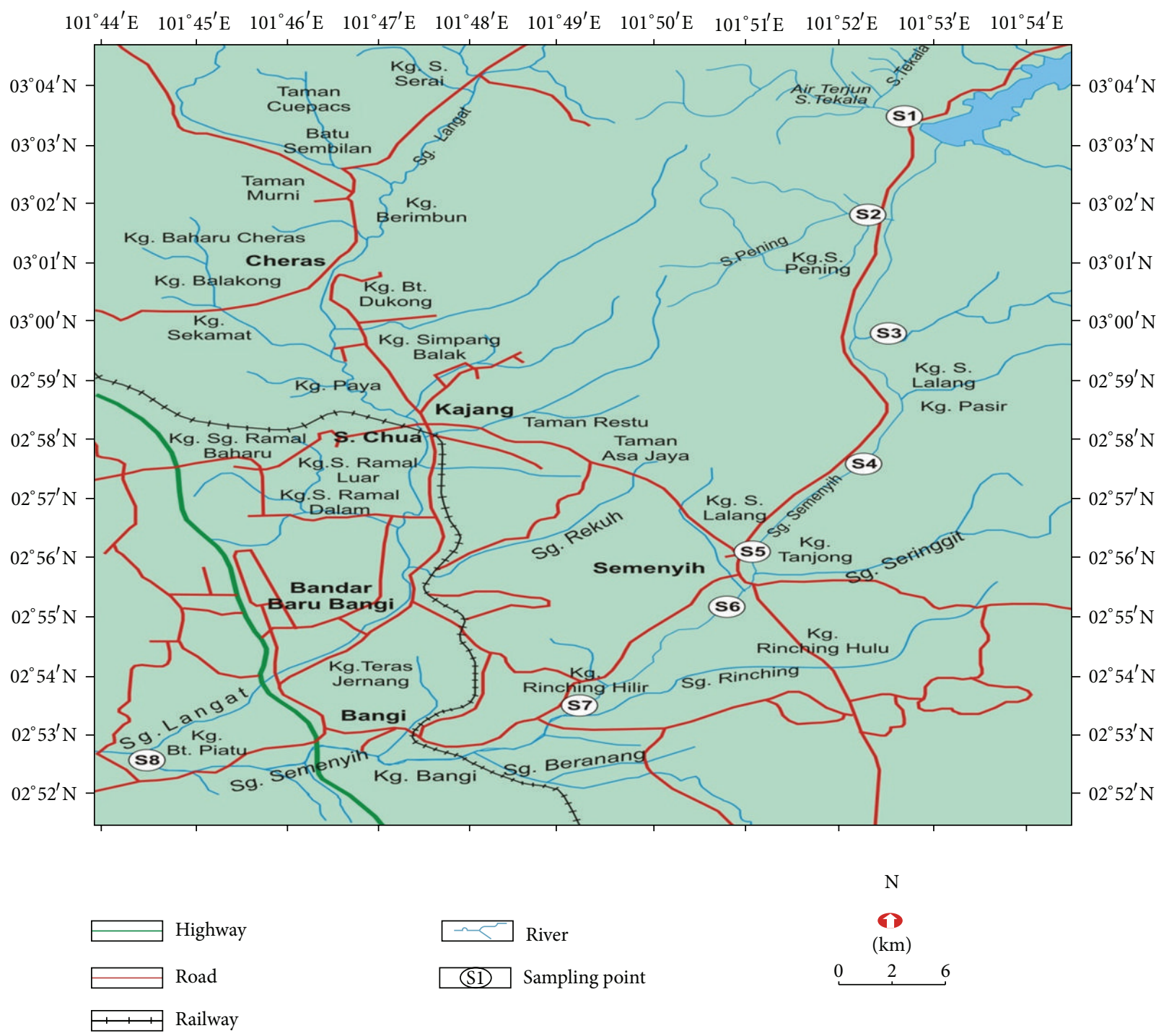

FIGURE 1: Study area and sampling stations along the Semenyih River.

industries, agricultural activities, and urban runoff which discharge into the river resulting in extensive variations in the water quality [11]. Generally, all of land use and anthropogenic activities pose a grievous threat not only to aquatic ecosystem in the river but also the provinces in which river water is used as domestic supply $[12,13]$, reported that Semenyih River is one of the rivers in Malaysia in which human activities associated with urbanization, industrialization, agricultural, and mining activities are extremely main sources of pollution. Moreover, the range of deterioration in water quality in the river varied depending on the percentage of change in land use. Therefore, the land use activities in the basin must be carefully planned and controlled on account of protecting the water resource and quality status. In this study, the physicochemical and microbiological parameters were measured and classified based on National Water Quality Standard (NWQS) to identify the effects of anthropogenic land use activities on the water quality condition. Moreover, the multivariate statistical techniques such as cluster analysis and principal component analysis were executed on the obtained data set to recognize water quality parameters for seasonal changes in the water quality of rivers, to evaluate the similarities and dissimilarities between sampling stations, and to determine the influence of pollution sources on the water quality parameters of the Semenyih River basin.

\section{Materials and Methods}

2.1. Study Area and Sampling Stations. The Semenyih River basin which has a total area of $266.60 \mathrm{~km}$ consists of 36 subbasins and 25 water catchment valleys with areas ranging from 1.37 to $35.57 \mathrm{~km}^{2}$ (Figure 1). The basin includes seven different main land uses such as settlements, industry, rubber and oil palm plantations, forests, industry, water bodies, and agricultural land. Semenyih basin lies between longitude $101^{\circ} 48^{\prime} 32.9^{\prime \prime} \mathrm{E}$ to $101^{\circ} 52^{\prime} 30.5^{\prime \prime} \mathrm{E}$ and latitude $02^{\circ} 54^{\prime} 14.9^{\prime \prime} \mathrm{N}$ to $03^{\circ} 03^{\prime} 23.1^{\prime \prime} \mathrm{N}$. The average annual rainfall of the area is 
about $3000 \mathrm{~mm}$. Furthermore, the river originates from the hilly and forested areas in the western slope of Banjaran Titiwangsa, northeast of Hulu [14, 15]. In addition, it flows southwards toward the provinces of Sepang and Hulu Langat. Furthermore, the river has been negatively influenced by industrial and urban wastes since the early 1990. Currently, the ingestion of drinking water of more than 1 million people is from the Semenyih River. The major attain of river can be considered to start from the Semenyih Dam flowing south-southwest trend throughout the town of Semenyih, Bangi Lama and lastly amalgamation with a Langat River at about $4 \mathrm{~km}$ to the east of Bangi Lama town as well as Pajam and Beranang Rivers which are also the feeder rivers for Semenyih River [16]. Overall, it is one of the main rivers in the state of Selangor, Malaysia, since the river is considered as a resource of cultivation and domestic water supply in Semenyih City, Bandar Tasek Kesuma, and Bandar Rinching after the treatment [15]. In this study eight sampling stations were selected along the river, from the upstream to downstream, and the selection criteria of the sampling locations were based on the characteristics of the water condition, land use, and anthropogenic activities along the river (Figure 1).

\subsection{Sampling Methods and Analytical Procedures. Water} sampling has been carried out twice during rainy and dry seasons 2012. Three water samples were collected from each station close to the right and left banks and in the middle of the river with triplicate. Water samples were collected in specific bottles according to [17]. Samples were stored in sterile glass flasks (bacteriology) and acid-washed plastic bottles (chemistry), cooled, transported to the laboratory, and processed within $6 \mathrm{~h}$ of collection. Temperature, dissolved oxygen (DO), conductivity, and $\mathrm{pH}$ were measured insitu as field parameters by YSI meter (model 1945), while $\mathrm{BOD}_{5}$, COD, TSS, O\&G, turbidity, $\mathrm{PO}_{4}, \mathrm{SO}_{4}, \mathrm{NO}_{3}, \mathrm{NH}_{3}-\mathrm{N}$, total hardness (TH), and fecal coliform (FC) were analyzed in the laboratory. $\mathrm{BOD}_{5}$ was analyzed as described by 5 -day test, and COD was assayed by means of the open reflux method [17]. Additionally, total suspended solids (TSS) and oil and grease $(\mathrm{O} \& \mathrm{G})$ were determined by total solids dried at $103-105^{\circ} \mathrm{C}$ and liquid-liquid, partition-gravimetric methods, respectively [17]. Moreover, turbidity, phosphate, sulfate, nitrate, and ammonia nitrogen were assayed by Absorptometric, Acid Ascorbic, Sulfa Ver 4, Cadmium Reduction, and Nessler methods, respectively $[17,18]$. Furthermore, total hardness was determined by convenient Inductive Coupled PlasmaMass Spectrometry (ICP-MS ug/L). Eventually, fecal coliform was determined based on the membrane filter technique [17]. The equipments were calibrated prior to use based on the manufacturer's directions.

2.3. Statistical Analysis. Statistical analysis of data was fulfilled using SPSS version 20. Analysis of variance (ANOVA) was carried out to determine the significant differences between sampling stations. Moreover, hierarchical cluster analysis (HCA) was executed by means of squared euclidean distances and the Ward's method to sort the variables of sampling stations and water quality indicators, respectively
[19]. Furthermore, analysis of variance (ANOVA) was used by Ward's method to determine the distances between clusters to reduce the squares sum of possible clusters at each step [25]. Additionally, principal component analysis (PCA)/factor analysis (FA) was accomplished to identify pollution factors influenced water quality. Otherwise, Bartlett's sphericity and Kaiser-Meyer-Olkin (KMO) tests were applied to a suitability examination of the data for FA. Nevertheless all analyzed data were standardized by scale transformation to ensure normal distributions for CA and FA [20].

\section{Result and Discussion}

\subsection{The Concentrations of Water Quality Parameters}

3.1.1. Temperature. Temperature values ranged from 26.27$27.55^{\circ} \mathrm{C}$ in the rainy season (RS) and $24.71-27.36^{\circ} \mathrm{C}$ in the dry season (DS) as shown in Figure 2(a). Station 8 in the downstream of both (DS) and (RS) recorded the highest value of $27.36^{\circ} \mathrm{C}$ and $27.55^{\circ} \mathrm{C}$, respectively. In addition, the results are within the standard acceptable levels of National Water Quality Standards, Malaysia (NWQS). Furthermore, the temperature was increased progressively from upstream to downstream, and statistically significant differences were found between stations (ANOVA, $P<0.05$ ). In contrast, the concentrations of temperature recorded in this study were approximately equivalent or less than those reported for the same basin (range $26^{\circ} \mathrm{C}-32^{\circ} \mathrm{C}$ ) by [13]. Generally, many factors such as the weather condition, sampling time, and location impact on the increase or decrease of temperature by which its role effect on the percentage of dissolved oxygen, biological activities, and other parameters [21].

3.1.2. $p H$. The $\mathrm{pH}$ values showed different values between the DR and RS in which higher average values of 8.41 are obtained at station 1 in the DS, whereas the lower average values of 5.23 is obtained at station 2 in the RS. In the RS, the highest $\mathrm{pH}$ was obtained at the downstream with the value of 6.55 , whereas the lowest value was obtained at station 2 with the value of 5.23 (Figure 2(b)). In the DS, the highest $\mathrm{pH}$ was obtained at the upstream with the value of 8.4 , whereas the lowest value was obtained at the downstream with the value of 7.07 (Figure 2(b)). On the other hand, these values were high compared with those reported by $[12,13]$ for the same basin range of 4.62 to 6.59 . Moreover, statistically significant differences were not found among sampling stations (ANOVA, $P>0.05$ ). However, the results are within the standard range and are classified under class I based on NWQS for Malaysian rivers. Generally, the $\mathrm{pH}$ concentration increase as a result of the photosynthetic algae activities that consumes carbon dioxide dissolved in [22]. Overall, the range of $\mathrm{pH}$ from 6.5 to 9 is mainly appropriate for aquatic life. Therefore it is very important to maintain the aquatic ecosystem within this range because high and low $\mathrm{pH}$ can be destructive in nature $[23,24]$.

3.1.3. Dissolved Oxygen. The dissolved oxygen (DO) of the water samples analyzed ranged from 5.58 to $7.07 \mathrm{mg} / \mathrm{L}$ during 


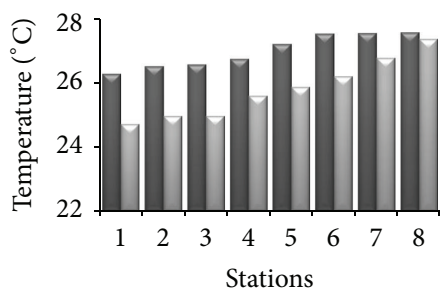

(a)

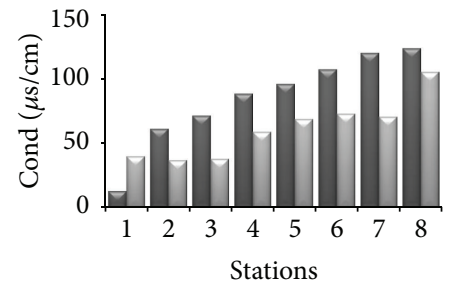

(d)

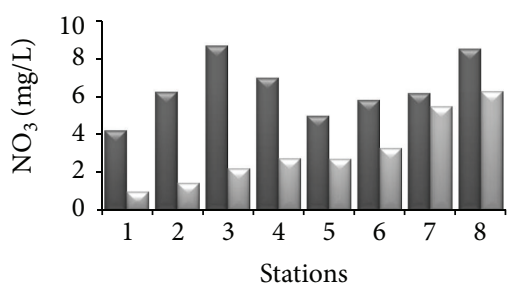

(g)

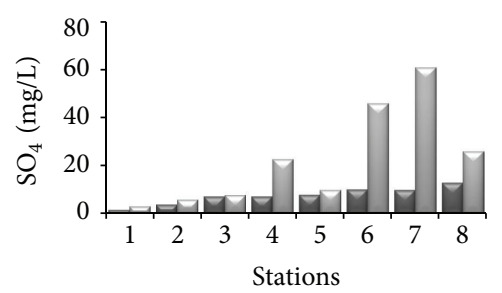

(j)

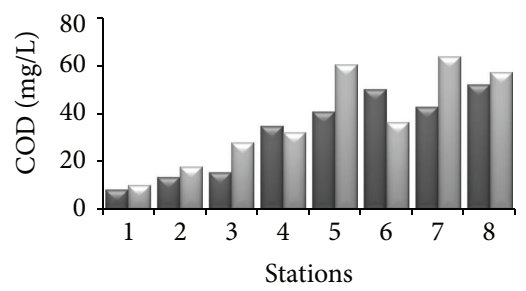

(m)

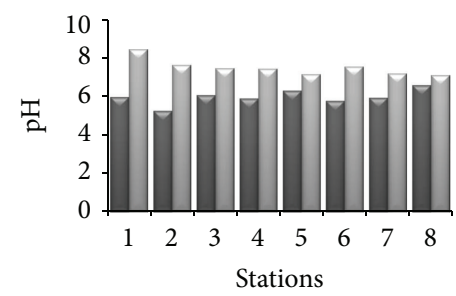

(b)

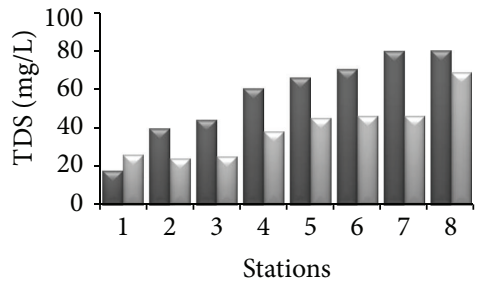

(e)

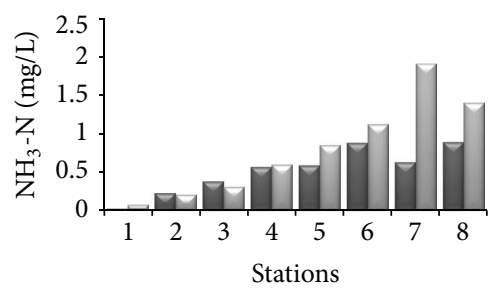

(h)

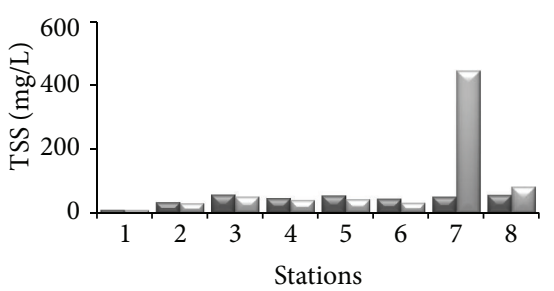

(k)

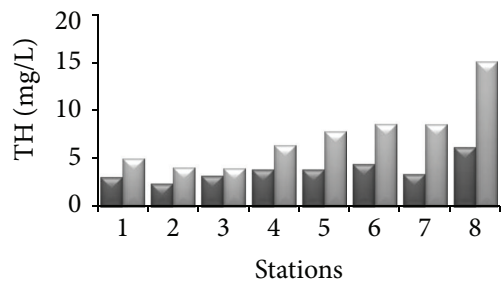

(n)

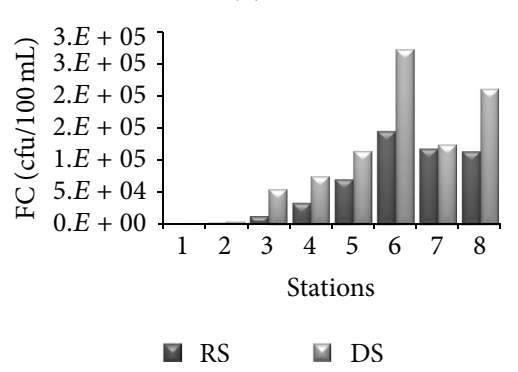

(p)

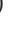

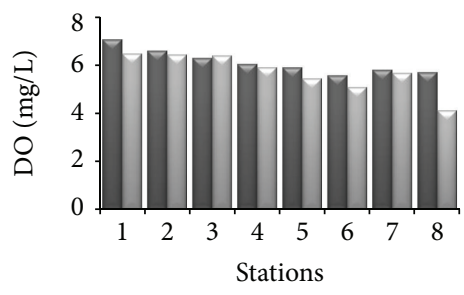

(c)

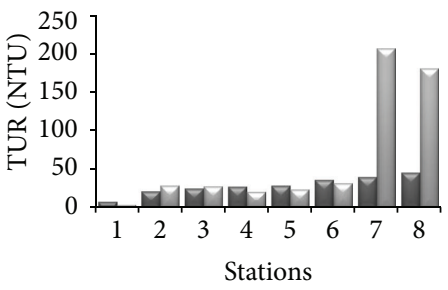

(f)

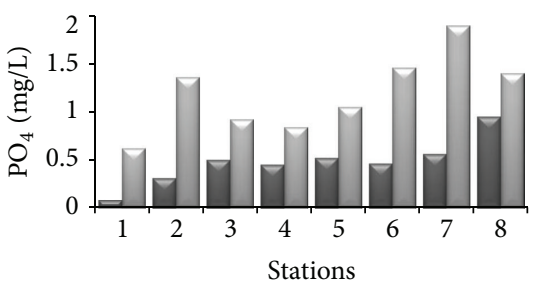

(i)

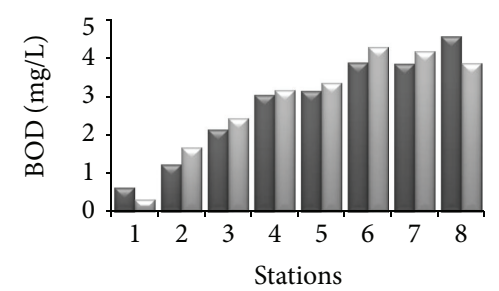

(1)

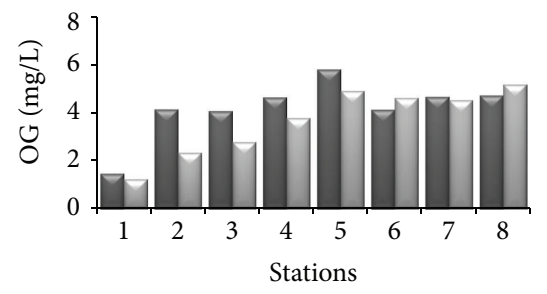

(o)

Figure 2: Distribution of values for (a) temperature, (b) pH, (c) DO, (d) conductivity, (e) TDS, (f) turbidity, (g) $\mathrm{NO}_{3}$, (h) $\mathrm{NH}_{3}-\mathrm{N},(\mathrm{i}) \mathrm{PO}_{4}$, (j) $\mathrm{SO}_{4}$, (k) TSS, (l) BOD, (m) COD, (n) TH, (o) OG and, and (p) FC between rainy and dry seasons, Semenyih River, Stations 1-8. 
RS, and from 4.13 to $7.44 \mathrm{mg} / \mathrm{L}$ during DS. The lowest DO was recorded at station 6 , while the highest value was at station 1 in the RS (Figure 2(c)). In the DS, the maximum value was at station 2 , while the least value was at station 8 (Figure 2(c)). In addition, these results are within the standard acceptable levels of NWQS for Malaysian river, which is more than $3 \mathrm{mg} / \mathrm{L}$ as well as categorized under class II. Furthermore, statistically significant differences were found between stations and seasons (ANOVA, $P \leq 0.05$ ). Additionally, values of DO found by [13] in their study of the same basin were below $4.0 \mathrm{mg} / \mathrm{L}$ with a lower value of $2.65 \mathrm{mg} / \mathrm{L}$ in the second station, while stations 1 and $3 \mathrm{had}$ DO values above $4 \mathrm{mg} / \mathrm{L}$ and the maximum being $6 \mathrm{mg} / \mathrm{L}$. The DO level found in all the stations is adequate for the planktons to survive and to do various physiological activities [24]. Overall, oxygen generally becomes dissolved in surface waters as a result of diffusion from the atmosphere and aquatic-plant photosynthesis. In general, dissolved oxygen is consumed by the degradation of organic matter in water [25].

3.1.4. Electrical Conductivity. In the RS, conductivity varied from 13 and $124 \mu \mathrm{s} / \mathrm{cm}$, and the lowest value of conductivity was observed at station 1 , while the highest was at station 8 (Figure 2(d)). Likewise, the variation of conductivity during DS was from 37 to 105.7, and the maximum value of conductivity was observed at station 8 , whereas the minimum was at station 2 (Figure 2(d)), so the conductivity was found to be within the recommended level by NWQS, Malaysia, and fell into the class I and significant differences were not found between stations (ANOVA, $P>0.05$ ). However, the conductivity values are lower compared to the values obtained by [13] in their study area which was between 46 and $231 \mu \mathrm{s} / \mathrm{cm}$. Normally, conductivity in the water was affected by the inorganic dissolved solids such as calcium, chloride, aluminum cations, nitrate, sulfate, iron magnesium, and sodium. On the other hand, organic compounds such as oil, alcohol, phenol, and sugar that can influence the water conductivity as well as the temperature also have an effect on the conductivity [12]. Generally, most of the freshwaters conductivity is ranging from 10 to $1000 \mu \mathrm{S} / \mathrm{cm}$. Nevertheless, the concentration can exceed about $1000 \mu \mathrm{S} / \mathrm{cm}$ in the water that receiving pollution [26].

3.1.5. Total Dissolved Solids. The values of total dissolved solids (TDS) in the RS are ranging from 17.66 to $80 \mathrm{mg} / \mathrm{L}$. The highest value obtained was $80 \mathrm{mg} / \mathrm{L}$ recorded at station 8 , and the lowest value obtained was $17.66 \mathrm{mg} / \mathrm{L}$ at station 1 (Figure 2(e)). In addition, the TDS concentrations in the DS ranged from 24 to $68.66 \mathrm{mg} / \mathrm{L}$. The highest concentration was $68.66 \mathrm{mg} / \mathrm{L}$ recorded at station 8 , and the lowest concentration was $24 \mathrm{mg} / \mathrm{L}$ at station 2 (Figure 2(e)). In this study, the concentrations of TDS were less than those reported for the same basin (range 108-504 mg/L) by [13]. Moreover, It was noticed that upstream stations have lower TDS values compared to the downstream ones because anthropogenic and land use activities were much less at upstream stations. Besides, TDS results are within the standard allowable levels of Malaysian rivers and are classified as class I determined by NWQS [23]. ANOVA result showed that there is no significant difference $(P>0.05)$ in TDS between stations. The high TDS concentration in the rivers is attributed to presence extreme anthropogenic activities along the river course and runoff with high suspended matter [27].

3.1.6. Turbidity. Turbidity values varied between 8 and 46 NTU during RS. Station 8 in the downstream recorded the high turbidity of $46 \mathrm{NTU}$, while the lowest value was 8 NTU recorded in the upstream (Figure 2(f)). In a similar manner, turbidity values ranged from 4 to 206.7 NTU during DS, the lowest turbidity of 4 NTU was recorded station 1, while the highest value was 206.7 NTU at station 7 in the downstream (Figure 2(f)). In addition, these concentrations were within standard permissible limits of NWQS for Malaysian rivers and categorized as class II [23]. However, this may be ascribed to the effluent from livestock farms, heavy precipitation, organic contamination and agriculture, and road runoff in which a high suspended matter content (UNESCO/WHO/UNEP, 2001). Additionally, compared to [15], turbidity values ranged from 30 to 245 NTU. Furthermore, turbidity concentrations in this study were higher than 15 NTU at most stations where the concentration below 25 NTU is still permissible for domestic use (DOE, 2006; [24]). Moreover, when compared to the sampling stations, turbidity was not significantly different (ANOVA, $P>0.05$ ). Overall, the excessive turbidity is generally related to possible microbiological contamination because water disinfection contained elevated turbidity is very complicated [28]. Prevalently, turbidity is resulted from the presence of suspended particles such as silt, plankton, clay, organic matter, and other microscopic or decomposers organisms. Generally, the clarity water decreased as a result of the presence of these suspended particles that deposited in the water. The murkier water in general was ascribed to the higher amount of sediments. This can also be the indicator of a high measured turbidity, and stream flow, surface runoff, and overland flow in natural waters also increase the turbidity levels in the water [29].

3.1.7. Nitrate. The nitrate $\left(\mathrm{NO}_{3}\right)$ concentrations ranged from 4.23 to $8.53 \mathrm{mg} / \mathrm{L}$ in the RS, where the highest concentration was recorded at station 8 and the lowest at station 1 (Figure $2(\mathrm{~g})$ ). Likewise, the nitrate values ranged from 1 to $6.3 \mathrm{mg} / \mathrm{L}$ during the DS, and the maximum value was recorded at station 6 , while the lowest was at station 1 (Figure $2(\mathrm{~g})$ ). In addition, the nitrate values in this study were within the maximum permissible limit set by NWQS, Malaysia, which is $7 \mathrm{mg} / \mathrm{L}$ and is classified as a class IV [23]. Furthermore, there were no significant differences between stations of nitrate (ANOVA, $P>0.05$ ). Approximately similar condition for nitrate was reported in the same basin ranging from 4.5 to $15.4 \mathrm{mg} / \mathrm{L}$ [13]. Commonly, nitrate is a naturally occurring form of nitrogen which is very mobile in water. River water which is high in nitrate levels is potentially harmful to human and animal health; in fresh water or estuarine systems close to land, nitrate can reach high levels that can cause death of aquatic life. However, nitrate is much less toxic than ammonia and nitrite [30]. 
3.1.8. Ammonia-Nitrogen. The ammonia-nitrogen $\left(\mathrm{NH}_{3}-\mathrm{N}\right)$ concentrations of water samples ranged between minimum $0.02 \mathrm{mg} / \mathrm{L}$ at station 1 and maximum $0.89 \mathrm{mg} / \mathrm{L}$ at station 8 during RS (Figure 2(h)), whereas in DS, they ranged between minimum 0.08 at station 3 and maximum $1.91 \mathrm{mg} / \mathrm{L}$ at station 7 (Figure 2(h)). According to the NWQS, the maximum threshold level of $\mathrm{NH}_{3}-\mathrm{N}$ for Malaysian rivers which support aquatic life is $0.9 \mathrm{mg} / \mathrm{L}[23,24]$. Nevertheless, the concentration of $\mathrm{NH}_{3}-\mathrm{N}$ was within this level range and is classified as class III. In addition, there were no significantly differences in $\mathrm{NH}_{3}-\mathrm{N}$ between stations (ANOVA, $P>0.05$ ). In this study, the concentrations of $\mathrm{NH}_{3}-\mathrm{N}$ were less than those reported for the same basin (range $0.78-2.75 \mathrm{mg} / \mathrm{L}$ ) by [13] and higher than those (range $0.14-0.40 \mathrm{mg} / \mathrm{L}$ ) reported by [12]. At all events, higher $\mathrm{NH}_{3}-\mathrm{N}$ values can be toxic to fish, but in small concentrations, it could serve as nutrients for excessive growth of algae [31].

3.1.9. Phosphate. The concentrations of phosphate $\left(\mathrm{PO}_{4}\right)$ ranged from 0.08 to $0.95 \mathrm{mg} / \mathrm{L}$ in the $\mathrm{RS}$ and 0.62 to $1.9 \mathrm{mg} / \mathrm{L}$ during DS. The highest value of $\mathrm{PO}_{4}$ in the $\mathrm{RS}$ was recorded in station 8 , while the least one was recorded at station 1 (Figure 2(i)). On the other hand, the maximum concentration of $\mathrm{PO}_{4}$ during DS was recorded at station 7 , while the minimum was recorded at station 1 (Figure 2(i)). Besides, there was no significance difference in $\mathrm{PO}_{4}$ between stations (ANOVA, $P>0.05$ ). These values generally exceed the normal level of NWQS for Malaysian rivers which is $0.2 \mathrm{mg} / \mathrm{L}$, hence, they were falling into class $\mathrm{V}$. In addition, results were high if compared to the results of the same basin recorded by $[12,13]$ which ranged from 0.35 to $0.92 \mathrm{mg} / \mathrm{L}$ and from 0.06 to $0.9 \mathrm{mg} / \mathrm{L}$, respectively. Overall, high concentrations of phosphates are generally indication of the pollution associated with eutrophication condition [32]. Moreover, domestic effluents particularly which contain detergents, fertilizer runoff, and industrial wastewater are the main reasons of high phosphate levels in surface water such as rivers and lakes [15].

3.1.10. Sulfate. The sulfate $\left(\mathrm{SO}_{4}\right)$ values varied from 1.67 to $13 \mathrm{mg} / \mathrm{L}$ during RS and from 3.23 to $61 \mathrm{mg} / \mathrm{L}$ during DS. The maximum $\mathrm{SO}_{4}$ was recorded at station 8 , while the minimum value was at station 1 in the RS (Figure $2(j)$ ). In addition, the maximum value in the DS was recorded at station 7 , while the minimum was at station 1 (Figure $2(\mathrm{j})$ ). Moreover, the sulfate values of water samples studied fell within the acceptable limit of NWQS for Malaysian rivers and were categorized as class I. Likewise, statistical analysis showed that no significant differences found between stations (ANOVA, $P>0.05$ ). According to [33], the major sources of sulfate in rivers are rock weathering, volcanoes, and human activities such as mining, waste discharge, and fossil fuel combustion process.

3.1.11. Total Suspended Solids. The total suspended solids (TSS) values of water samples ranged between minimum $11.7 \mathrm{mg} / \mathrm{L}$ at station 1 and maximum $58.1 \mathrm{mg} / \mathrm{L}$ at station 8 in the RS (Figure $2(\mathrm{k})$ ), whereas in DS, they ranged between minimum $10.3 \mathrm{mg} / \mathrm{L}$ at station 3 and maximum $446 \mathrm{mg} / \mathrm{L}$ at station 7 (Figure 2(k)). In addition, ANOVA result showed that there is no significant difference $(P>0.05)$ in TSS between stations. Based on the NWQS, the maximum threshold limit of TSS for Malaysian rivers which support aquatic life is $150 \mathrm{mg} / \mathrm{L}[23,24]$. However, the TSS values in this study were within this limit and were categorized as class III except station 7 during DS in which TSS exceeded due to bridge construction. Furthermore, the TSS values are lower compared to the values mentioned by [13] and greater compared to the values reported by [12] in the study of water quality assessment of the Semenyih River basin which were between 30 and $308 \mathrm{mg} / \mathrm{L}$ and 28 and $107.14 \mathrm{mg} / \mathrm{L}$, respectively. Normally, soil erosion considers the source for suspended solids that comes from the surrounding area caused by human activities. For example, rainy season stations recorded the highest value of TSS due to the rainy days which stimulated serious erosion on the two sides of the riverbanks along the river. In addition, the TSS concentrations increased starting from station 3, which recorded relatively high siltation because of deforestation, mining, and plantation activities along the river.

3.1.12. Biochemical Oxygen Demand. The biochemical oxygen demand (BOD) of the river was ranging between 0.63 and $4.56 \mathrm{mg} / \mathrm{L}$ in the RS (Figure 2(l)) and from 0.32 to $4.28 \mathrm{mg} / \mathrm{L}$ during DS (Figure 2(1)). In the RS, the highest BOD was recorded in the downstream at station 8 , whereas the lowest was recorded at station 1 in the upstream. Furthermore, the maximum value in the DS was recorded at station 6 , while the minimum was at station 1 . Moreover, the BOD variation between stations was significantly different (ANOVA, $P<0.05$ ). Additionally, the BOD values of surface water were within the recommended permissible limit by NWQS and were categorized as class II. According to [13], the concentrations of BOD varied from 2.4 to $19.8 \mathrm{mg} / \mathrm{L}$ which are considered high if compared to this study. The BOD concentration continuously increases because of natural plant decaying process and other contributors that increase the total nutrient in water bodies such as fertilizer, construction effluent, animal farm, and septic system [34]. BOD concentration is directly associated with DO concentrations. High value of BOD shows decline in DO. This phenomenon is common as identified in many previous researches [24].

3.1.13. Chemical Oxygen Demand. The chemical oxygen demand (COD) concentrations of water samples were fluctuating between minimum $8.6 \mathrm{mg} / \mathrm{L}$ at station 1 and maximum $52.3 \mathrm{mg} / \mathrm{L}$ at station 8 in the RS (Figure $2(\mathrm{~m})$ ), whereas in DS, they were fluctuating between minimum $10.4 \mathrm{mg} / \mathrm{L}$ at station 1 and maximum $63 \mathrm{mg} / \mathrm{L}$ at station 7 (Figure 2(m)). In addition, these results are within the standard allowable limit of National Water Quality Standards, Malaysia (NWQS), which is $50 \mathrm{mg} / \mathrm{L}$ or less and is classified as class III [23]. Moreover, statistically significant differences of COD were found between stations (ANOVA, $P<0.05$ ). Generally, the lower COD level indicates a low level of pollution, while the high level of COD points out the high level of pollution of water in the study area [28]. Moreover, a wide usage of chemical and organic fertilizer and discharge of sewage affect COD level, while the high COD pointing to a deterioration of 
the water quality is attributed to the discharge of municipal effluent [35].

3.1.14. Total Hardness. The total hardness $(\mathrm{TH})$ values ranged between minimum $6.2 \mathrm{mg} / \mathrm{L}$ at station 2 and maximum $2.4 \mathrm{mg} / \mathrm{L}$ at station 8 during RS (Figure 2(n)), whereas in DS, they ranged between minimum $3.9 \mathrm{mg} / \mathrm{L}$ at station 3 and maximum $15.1 \mathrm{mg} / \mathrm{L}$ at station 8 (Figure 2(n)). Moreover, the concentration of hardness in all stations did not pose any water quality problems because the hardness concentration was on the recommended limit of National Water Quality Standards, Malaysia (NWQS), which is $250 \mathrm{mg} / \mathrm{L}$ and is classified as class I [23]. In addition, statistically significant differences of TH were not found between stations (ANOVA, $P>0.05)$. Generally, the total hardness is a function of the geology of the area with which the surface water is associated. Hardness has no known adverse influences health; nevertheless, some evidence has been given to point out its impact on heart diseases [36].

3.1.15. Oil and Grease. Oil and grease (OG) values during RS varied from 1.46 to $5.81 \mathrm{mg} / \mathrm{L}$. The lowest value was recorded at station 1, while the highest was at station 5 (Figure 2(o)). Additionally, oil and grease values during DS ranged from minimum $1.22 \mathrm{mg} / \mathrm{L}$ at station 1 to maximum $5.18 \mathrm{mg} / \mathrm{L}$ at station 8 (Figure 2(o)). In addition, ANOVA results showed that statistically significant differences $(P>0.05)$ were found between stations of oil and grease. Overall, the oil and grease values in this study were within the permissible limit set by NWQS for Malaysian rivers and were classified as class III [23].

3.1.16. Fecal Coliform. The fecal coliform (FC) concentrations were ranging between minimum $433 \mathrm{cfu} / 100 \mathrm{~mL}$ to station 1 and maximum $145667 \mathrm{cfu} / 100 \mathrm{~mL}$ at station 6 during RS (Figure 2(p)), while in the DS, they were ranging between minimum $867 \mathrm{cfu} / 100 \mathrm{~mL}$ at station 1 and maximum $273333 \mathrm{cfu} / 100 \mathrm{~mL}$ at station 6 (Figure 2(p)). Moreover, the FC was increased progressively, but it was drastically at station 6 which receives high amounts of effluents contained greater concentrations from the livestock farms (poultry, goats, and cow farms) located a few meters before this station. In addition, results showed that there are significant differences of FC between stations (ANOVA, $P<0.05$ ). Furthermore, the FC values in this study were exceeded the recommended maximum allowable limit by NWQS for Malaysian rivers which is $5000 \mathrm{cfu} / 100$, therefore, they were categorized as class $\mathrm{V}[23,37]$. It is reported that fecal coliform levels were lower at high temperature, high dissolved oxygen, and high $\mathrm{pH}$; this indicated that one of the fecal coliform sources could be related to human recreational activities [34, 35]. It is mentioned that FC can survive and multiply in irrigation water, wastewater, subtropical sediments, and mineral water.

\subsection{Hierarchical Cluster Analysis (HCA) of Water Quality} Data. Hierarchical cluster analysis (HCA) was executed to determine the correspondence between the sampling stations in the study area. It classified the eight sampling stations into three statistically significant clusters at $\left(D_{\text {link }} / D_{\max }\right) * 25<5$

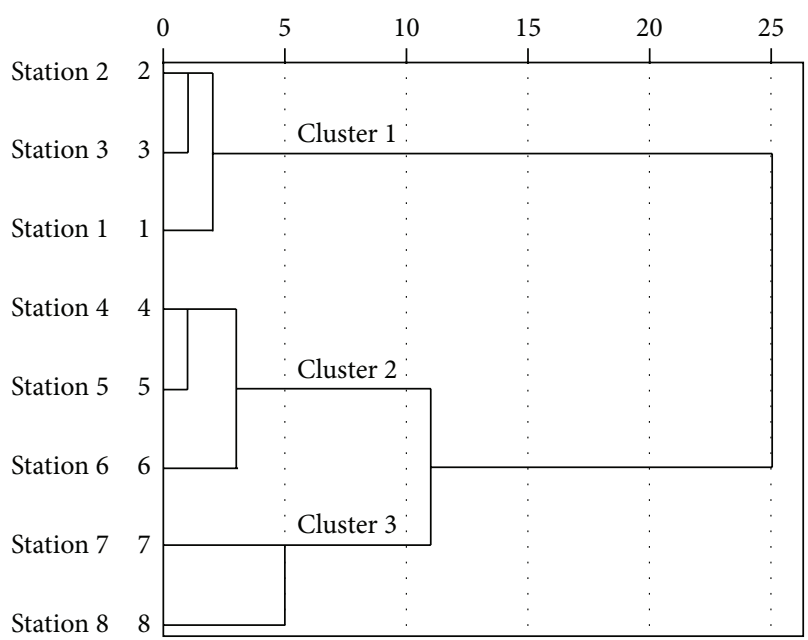

Figure 3: Dendrogram of cluster analysis of the water quality data.

in which resulted a dendrogram (Figure 3). According to the sixteen parameters, HCA categorized eight sampling stations into three distinctive clusters described based on pollution magnitude as clean, slightly polluted, and polluted. Stations 1 , 2 , and 3 formed clusters 1 , while cluster 2 comprised stations 4,5 , and 6 as well as stations 7 and 8 formed cluster 3 . In cluster 1 , the sampling stations in particular station 1 were located in the upstream which was surrounded by extended forest covering. Generally, the upstream area of rivers is covered with intensely forest covering [38]. In addition, human activities at this station were limited except some recreational activities at upstream waterfall; therefore the condition of water quality was slightly clean and optimized. Besides stations 2 and 3 were located after station 1 and had similar characteristic which were influenced by parallel pollution sources as a result of the land use changed from forest to agriculture and unplanned settlements [9]. Sampling stations of cluster 2 were located in the middle of the river and affected by land use and anthropogenic activities. Station 4 receives pollution from mining, agricultural activities, and domestic effluents of unsewered areas, whereas station 5 was affected by industrial activities, surface runoff, and wastewater from the Semenyih city [12]. Moreover, station 6 appears to be largely influenced by the livestock husbandry and small dumps leaches placed on the banks of course, and hence water quality was found to be highly polluted by livestock farming activities $[9,12,13]$. In cluster 3 , stations 7 and 8 were located in the downstream and influenced by the increase flow rate, deforestation, palm plantation, runoff from agricultural fields, and discharge of vehicles washing and workshops. Overall, the river at these stations was expended and more rapidly moving but become shallower because of alluviation and erosion of the river banks. Additionally, the land use in this area comprised industries and settlements, which covered Bangi, Rinching, Beranang, and Broga [9]. Therefore, the minimum water quality was recorded at station 8 that received contamination from point and nonpoint sources that represented above. Eventually, the result denotes that $\mathrm{HCA}$ is a positive multivariate technique to assess and 


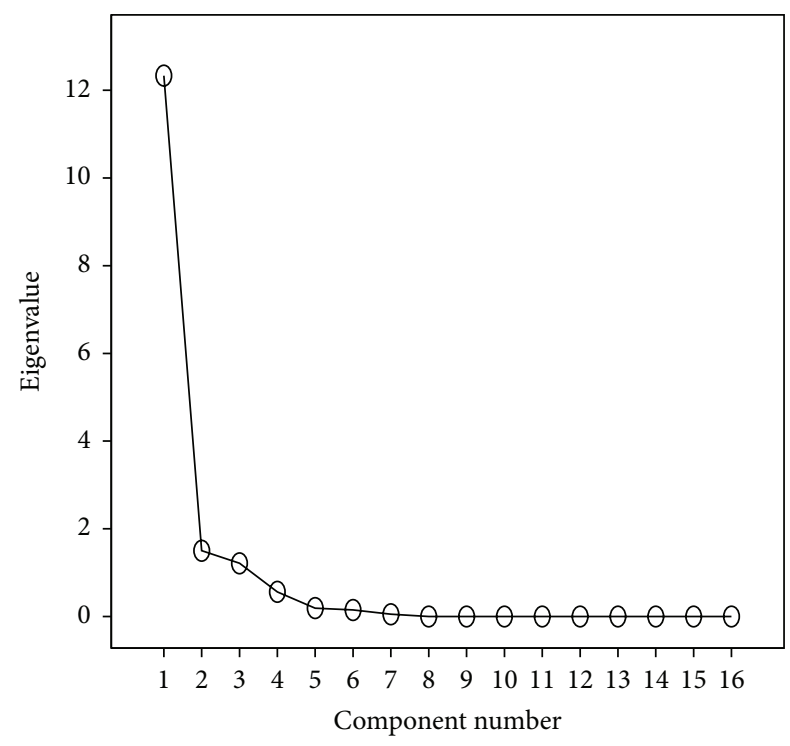

FIGURE 4: Scree plots of the factor model of the sampling stations.

TABLE 1: The factor loadings after varimax rotation of the water quality data.

\begin{tabular}{lccc}
\hline W.Q. parameters & \multicolumn{3}{c}{ Factors } \\
\hline Temperature & 0.94 & F 2 & F 3 \\
pH & 0.18 & 0.14 & 0.26 \\
Cond & 0.86 & 0.48 & 0.86 \\
$\mathrm{DO}$ & -0.89 & -0.38 & 0.15 \\
$\mathrm{TDS}$ & 0.89 & 0.39 & -0.17 \\
$\mathrm{SO}_{4}$ & 0.78 & 0.45 & 0.17 \\
$\mathrm{NO}_{3}$ & -0.04 & 0.86 & 0.42 \\
$\mathrm{PO}_{4}$ & 0.54 & 0.62 & 0.34 \\
$\mathrm{TUR}$ & 0.81 & 0.46 & 0.53 \\
$\mathrm{NH}_{3} \mathrm{~N}$ & 0.87 & 0.32 & 0.29 \\
$\mathrm{BOD}$ & 0.51 & 0.81 & 0.32 \\
$\mathrm{COD}$ & 0.86 & 0.34 & 0.14 \\
$\mathrm{TSS}$ & 0.93 & 0.15 & 0.37 \\
$\mathrm{TH}$ & 0.52 & 0.17 & 0.32 \\
$\mathrm{OG}$ & 0.61 & 0.65 & 0.80 \\
$\mathrm{FC}$ & 0.94 & -0.02 & -0.13 \\
Variance \% & 55.93 & 21.65 & 0.26 \\
Cumulative \% & 55.93 & 77.58 & 16.47 \\
\hline
\end{tabular}

classify surface water in the Semenyih River basin. At the same time, it is significant to a large extent to authorities and decision makers to know the latest information on the river which help them in the optimal strategy establishment in which sampling stations and experimental analysis cost can be reduced.

3.3. Principal Component Analysis (PCA) of Water Quality Data. Factor analysis or principal component analysis (PCA) was accomplished on the standardized data sets for the eight sampling stations as represented by cluster analysis to classify the factors affected on each water sample and evaluate the composition structure among them. Factor analysis of the data sets outputs three factors with total variance $94.05 \%$ and is based on the scree plot when eigenvalues $>1$ (Figure 4 ). The significance of factor is determined by the eigenvalue [39]. Consider that eigenvalues of 1.0 or larger are significant. In addition, factors loading were classified to strong, moderate, and weak based on loading values of greater than $0.75,0.75-$ 0.50 , and $0.50-0.30$, respectively [40]. On the other hand, the data set of 16 water quality parameters comprised three loading factors (Table 1). Factor 1 is the most important with $55.93 \%$ of the total variance with strong significant loading of temperature, conductivity, TDS, $\mathrm{SO}_{4}$, turbidity, $\mathrm{NH}_{3}-\mathrm{N}, \mathrm{COD}$, TSS, and fecal coliform as well as moderate loadings on $\mathrm{PO}_{4}, \mathrm{BOD}, \mathrm{TH}$, and $\mathrm{OG}$, whereas $\mathrm{DO}$ points out strongly negative loading, which stands for organic and inorganic contamination from domestic effluent besides point and nonpoint source contamination. In addition, these variables indicate pollution associated with industrial, mining, anthropogenic, and land use activities. This was largely expected because the industrial and domestic effluent of Bangi and Semenyih cities that discharge their wastewater directly into Semenyih River. Factor 2 shows about 21.65\% of total variance. It has two parameters with strong positive loadings, namely, $\mathrm{BOD}$ and $\mathrm{NO}_{3}$. Furthermore, $\mathrm{PO}_{4}$ and $\mathrm{OG}$ show moderate positive loading. Therefore, these parameters are attributed to products from anthropogenic activities with extremely urban impacts. Moreover, pollution can be accompanied with cultivation of the surrounding regions where phosphate and nitrogen fertilizers are utilized. Factor 3 shows about $16.47 \%$ of the total variance and has only two parameters with strong significant loadings that are $\mathrm{pH}$ and $\mathrm{TH}$, while it shows only $\mathrm{PO}_{4}$ with moderate loading, thus, this factor attributes pollution to industrial activities and domestic wastewater. In this study, the data reduction from factor analysis is great unlike expected, principally because 13 parameters of the 16 (exceeded 60\%) measured explanation $94.05 \%$ of the data variance. Therefore, factor analysis was used as an effective technique to categorize those parameters which basically contribute to alterations of the water quality, and also it provides a significant data reduction [41]. These results were fairly compatible with results of principal component analysis reported by [42] of the Behrimaz Stream (Turkey) that explained $88.93 \%$ of the total variance in water quality data sets of the river and generated five factors. In addition, factors obtained from PCA indicated that the parameters responsible for variations of water quality are principally associated with soluble minerals and temperature as natural sources as well as agricultural activities, domestic wastewater, and surface runoff from roads and villages as anthropogenic activities. Furthermore, the results of this study also were relatively compatible with those reported by [43] of the Jajrood River (Tehran, Iran), particularly in parameters responsible for water quality variables. The study stated that PCA yielded five factors with $85 \%$ of the total variance and recognized the natural parameters, the organic nutrients, and the inorganic parameters as the most significant parameters causing water 
quality variations of the river. On the other hand, this study was incompatible with the study reported by [44], where PCA did not result in a significant data reduction, but it was contributed to identify the factors responsible for variations in river water quality. Factors obtained from PCA indicated that parameters responsible for water quality variations are only related to domestic wastewater and industrial.

\section{Conclusion}

The water quality of the Semenyih River varies based on the seasons and location of the sampling stations. According to the NWQS for Malaysian rivers, temperature, $\mathrm{pH}$, conductivity, TDS, $\mathrm{SO}_{4}$, and $\mathrm{TH}$ were classified as class $\mathrm{I}$, while DO, turbidity, and BOD were categorized under class II, Therefore, these parameters were in the normal range. In addition, $\mathrm{NH}_{3}-\mathrm{N}$, TSS, COD, and OG were in the permissible limits and fall into class III, and $\mathrm{NO}_{3}$ was classified under class IV and reached the allowable threshold limit. On the contrary, $\mathrm{PO}_{4}$ and $\mathrm{FC}$ exceeded the allowable threshold levels, and hence, were categorized as class V. Therefore, the river was moderately polluted with $\mathrm{NH}_{3}-\mathrm{N}$, TSS, COD, and $\mathrm{NO}_{3}$, whereas it is extremely contaminated with $\mathrm{PO}_{4}$ and $\mathrm{FC}$. HCA classified 8 sampling stations into three clusters based on the similar water quality characteristics. Based on the latest obtained information, authorities and decision makers can design optimal strategy in which sampling stations, and experimental analysis costs can be reduced. Last but not least, PCA gives great unlike data reduction, because 13 parameters of the 16 (exceeded 60\%) measured represent $94.05 \%$ of the data variance. Hence, factor analysis was used as an effective technique to categorize those parameters which basically contribute to the alterations of the water quality; it also provides a significant data reduction. Eventually, the analysis indicated that the river water quality is slightly polluted. Therefore, the river water can be used for irrigation with precaution, and it is in need for any form of treatment to be used for domestic purposes.

\section{Acknowledgment}

The authors would like to express their appreciation to the Faculty of Science and Technology, Universiti Kebangsaan Malaysia for the use of their research facilities.

\section{References}

[1] J. Das and B. C. Acharya, "Hydrology and assessment of lotic water quality in Cuttack City, India," Water, Air, and Soil Pollution, vol. 150, no. 1-4, pp. 163-175, 2003.

[2] C. R. Ramakrishnaiah, C. Sadashivaiah, and G. Ranganna, "Assessment of water quality index for the groundwater in Tumkur taluk, Karnataka state, India," E-Journal of Chemistry, vol. 6, no. 2, pp. 523-530, 2009.

[3] A. Loukas, "Surface water quantity and quality assessment in Pinios River, Thessaly, Greece," Desalination, vol. 250, no. 1, pp. 266-273, 2010.

[4] K. P. Singh, A. Malik, and S. Sinha, "Water quality assessment and apportionment of pollution sources of Gomti river (India) using multivariate statistical techniques-a case study," Analytica Chimica Acta, vol. 538, no. 1-2, pp. 355-374, 2005.

[5] M. A. Massoud, M. El-Fadel, M. D. Scrimshaw, and J. N. Lester, "Factors influencing development of management strategies for the Abou Ali River in Lebanon. I: spatial variation and land use," Science of the Total Environment, vol. 362, no. 1-3, pp. 15-30, 2006.

[6] G. C. Sigua and W. A. Tweedale, "Watershed scale assessment of nitrogen and phosphorus loadings in the Indian River Lagoon basin, Florida," Journal of Environmental Management, vol. 67, no. 4, pp. 363-372, 2003.

[7] Y. W. Chen, C. X. Fan, K. Teubner, and M. Dokulil, "Changes of nutrients and phytoplankton chlorophyll-a in a large shallow lake, Taihu, China: an 8-year investigation," Hydrobiologia, vol. 506-509, pp. 273-279, 2003.

[8] DOE, Malaysia Environmental Quality Report, Department of Environment, Ministry of Science, Technology and EnvironmentMaskha Sdn Bhd, Kuala Lumpur, Malaysia, 2001.

[9] M. B. Gasim, M. M. Jamil, S. A. Rahim, and M. E. Toriman, "Water-quality assessment of the Langat River at kilometre 7, Jalan Kajang-Bangi, Selangor, Malaysia," Arab World Geographer, vol. 12, no. 3-4, pp. 188-198, 2009.

[10] Anon, Water Effluent From Pig Farms in Sabah-A Preliminary investigation of the Key Environmental Issue, State Environmental Conservation Department, Sabah, Malaysia, 2001.

[11] B. Raman, R. Bouwmeester, and S. Mohan, "Fuzzy logic water quality index and importance of water quality parameters," Air, Soil and Water Research, vol. 2, pp. 51-59, 2009.

[12] F. M. Al-Badaii, Water quality assessment of the Semenyih River [M.S. thesis], Universiti Kebangsaan Malaysia, Selangor, Malaysia, 2011.

[13] M. B. Gasim, B. S. Ismail, N. A. Wan, I. Y. Muhammad, and M. H. Marlia, "Water quality assessment of the Semenyih River basin langor, Malaysia," Jurnal Biosains, vol. 16, no. 1, p. 95, 2005.

[14] M. B. Gasim, "Land use changes in the Semenyih Watershed and their impacts on water quality," in Proceeding of the integrated Drainage Basin, Management and Modeling, pp. 207220, Geography Department, Universiti Kebangsaan Malaysia, Selangor, Malaysia, November 1999.

[15] M. B. Gasim, W. N. Azmin, and M. I. Yaziz, "Land use change and their impact on water quality in the Semenyih River, Selangor, Malaysia," Journal Technology Mineral, vol. 2, pp. 103111, 2012.

[16] DOE, Classification of Malaysian Rivers: Final Report on Development of Water Quality and Standards for Malaysia (Phase Iv-River Classification), Department of Environment, Kuala lumpur, Malaysia, 1994.

[17] APHA, Standard Methods for the Examination of Wastewater, America Public Health Association, Washington, DC, USA, 20th edition, 2003.

[18] HACH, DR/500 Spectrophotometer Procedure Manual, Hach Company, Loveland, Colo, USA, 2003.

[19] H. Bu, X. Tan, S. Li, and Q. Zhang, "Temporal and spatial variations of water quality in the Jinshui River of the South Qinling Mts., China," Ecotoxicology and Environmental Safety, vol. 73, no. 5, pp. 907-913, 2010.

[20] T. G. Kazi, M. B. Arain, M. K. Jamali et al., "Assessment of water quality of polluted lake using multivariate statistical techniques: a case study," Ecotoxicology and Environmental Safety, vol. 72, no. 2, pp. 301-309, 2009. 
[21] M. Shuhaimi-Othman, E. C. Lim, and I. Mushrifah, "Water quality changes in Chini Lake, Pahang, West Malaysia," Environmental Monitoring and Assessment, vol. 131, no. 1-3, pp. 279292, 2007.

[22] S. Gandaseca, N. Rosli, J. Ngayop, and C. I. Arianto, "Status of water quality based on the physico-chemical assessment on river water at wildlife sanctuary Sibuti Mangrove forest, Miri Sarawak," American Journal of Environmental Sciences, vol. 7, no. 3, pp. 269-275, 2011.

[23] DOE, Water Quality Index. Department of Environment. Ministry of Science, Technology and Environment Malaysia, Kuala Lumpur, Malaysia, 2006.

[24] N. Rosli, S. Gandaseca, J. Ismail, and M. I. Jailan, "Comparative study of water quality at different peat swamp forest of Batang Igan, Sibu Sarawak," American Journal of Environmental Sciences, vol. 6, no. 5, pp. 416-421, 2010.

[25] A. Astel, M. Biziuk, A. Przyjazny, and J. Namieśnik, “Chemometrics in monitoring spatial and temporal variations in drinking water quality," Water Research, vol. 40, no. 8, pp. 1706-1716, 2006.

[26] S. Harun, M. H. Abdullah, M. Mohamed et al., "Water quality study of four streams within Maliau Basin Conservation area, Sabah, Malaysia," Journal of Tropical Biology and Conservation, vol. 6, pp. 109-113, 2010.

[27] W. H. O. UNESCO//UNEP, Water Quality Assessment-A Guide to Use Biota, Sediment and Water in Environmental Monitoring, UNESCO/WHO/UNEP, Paris, France, 2nd edition, 2001.

[28] M. Waziri and V. O. Ogugbuaja, "Interrelationship between physicochemical water pollution indicators: a case study of River Yobe-Nigeria," Journal of Scientific \& Industrial Research, vol. 1, pp. 76-80, 2010.

[29] J. Yisa and T. Jimoh, "Analytical studies on water quality index of river Landzu," American Journal of Applied Sciences, vol. 7, no. 4, pp. 453-458, 2010.

[30] N. Romano and C. Zeng, "Effects of potassium on nitrate mediated alterations of osmoregulation in marine crabs," Aquatic Toxicology, vol. 85, no. 3, pp. 202-208, 2007.

[31] D. L. Corwin, K. Loague, and T. R. Ellsworth, "Advanced information technologies for assessing nonpoint source pollution in the Vadose Zone: conference overview," Journal of Environmental Quality, vol. 28, no. 2, pp. 357-365, 1999.

[32] WHO, Guidelines for Drinking Water Quality, WHO, Geneva, Switzerland, 2nd edition, 1998.

[33] J. D. Hem, "Study and interpretation of the chemical characteristics of natural water," US Geological Survey Water-Supply Paper, vol. 2254, 1985.

[34] E. M. Al-Sabahi, A Study of Surface Water and Groundwater Pollution in Ibb City, Yemen [Ph.D. thesis], Universiti Kebangsaan Malaysia, Selangor, Malaysia, 2007.

[35] M. Eisakhani and A. Malakahmad, "Water quality assessment of bertam river and its tributaries in Cameron Highlands, Malaysia," World Applied Sciences Journal, vol. 7, pp. 769-776, 2009.

[36] L. W. Wright, A microbial and chemical water quality study of sixteen individual wells in rural southern Cochise County, Arizona [M.S. thesis], University of Arizona, Tucson, Ariz, USA, 2010.

[37] H. W. Pearson, D. D. Mara, S. W. Mills, and D. J. Smallman, "Physico-chemical parameters influencing faecal bacterial survival in waste stabilization ponds," Water Science and Technology, vol. 19, no. 12, pp. 145-152, 1987.
[38] Z. Shen, Q. Zhang, C. Yue et al., “The spatial pattern of land use/land cover in the water supplying area of the Middle-Route of the South-to-North Water Diversion (MR-SNWD) Project," Acta Geographica Sinica, vol. 61, no. 6, pp. 633-644, 2006.

[39] Q. Zhang, Z. Li, G. Zeng et al., "Assessment of surface water quality using multivariate statistical techniques in red soil hilly region: a case study of Xiangjiang watershed, China," Environmental Monitoring and Assessment, vol. 152, no. 1-4, pp. 123-131, 2009.

[40] C. W. Liu, K. H. Lin, and Y. M. Kuo, "Application of factor analysis in the assessment of groundwater quality in a blackfoot disease area in Taiwan," Science of the Total Environment, vol. 313, no. 1-3, pp. 77-89, 2003.

[41] D. W. Alberto, D. M. Pilar, and M. A. Valeria, "PAttern recognition techniques for the evaluation of spatial and temporal variations in water quality. A case study: Suquiá River basin (Co’rdoba-Argentina)," Water Research, vol. 35, pp. 2881-2894, 2001.

[42] M. Varol and B. Şen, "Assessment of surface water quality using multivariate statistical techniques: a case study of Behrimaz Stream, Turkey," Environmental Monitoring and Assessment, vol. 159, no. 1-4, pp. 543-553, 2009.

[43] H. Razmkhah, A. Abrishamchi, and A. Torkian, "Evaluation of spatial and temporal variation in water quality by pattern recognition techniques: a case study on Jajrood River (Tehran, Iran)," Journal of Environmental Management, vol. 91, no. 4, pp. 852-860, 2010.

[44] Q. Zhang, Z. Li, G. Zeng et al., "Assessment of surface water quality using multivariate statistical techniques in red soil hilly region: a case study of Xiangjiang watershed, China," Environmental Monitoring and Assessment, vol. 152, no. 1-4, pp. 123-131, 2009. 

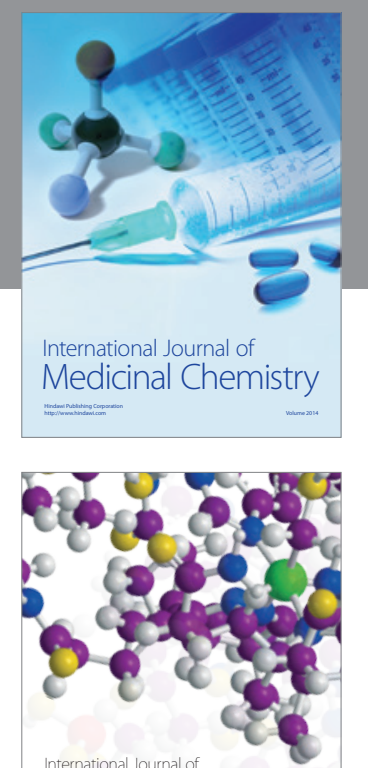

\section{Carbohydrate} Chemistry

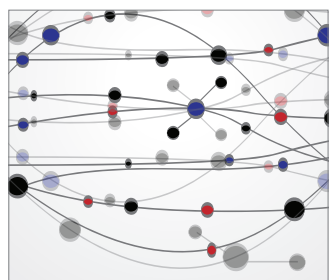

The Scientific World Journal
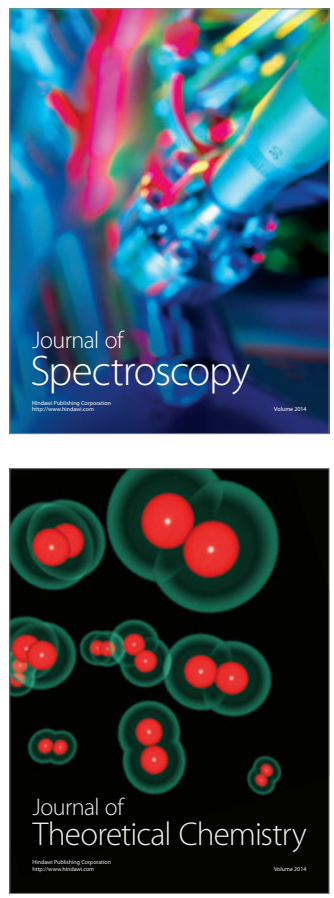
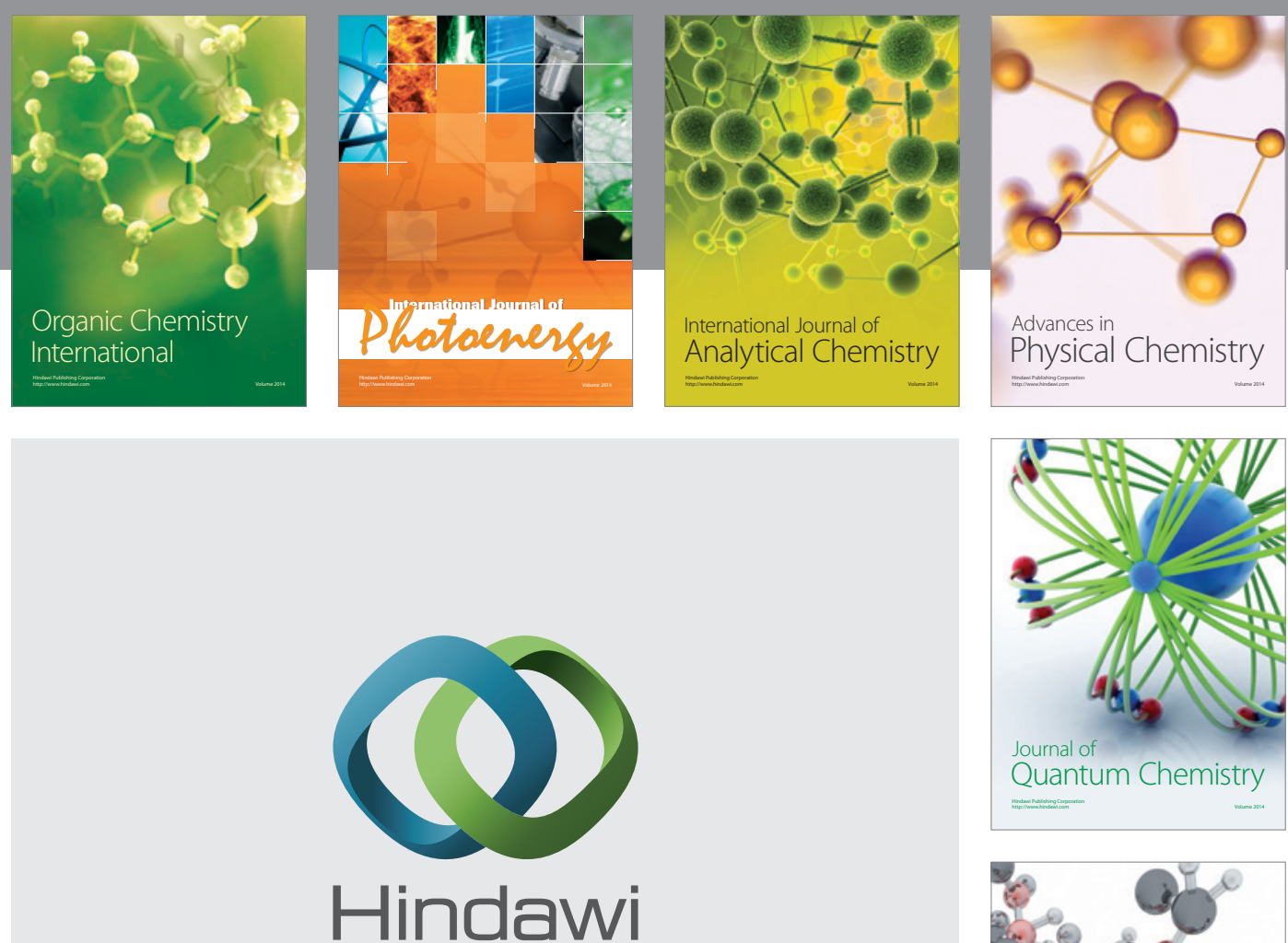

Submit your manuscripts at

http://www.hindawi.com

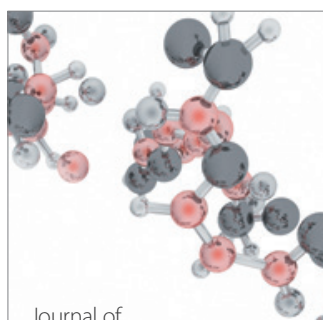

Analytical Methods

in Chemistry

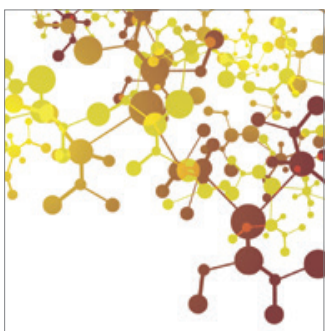

Journal of

Applied Chemistry

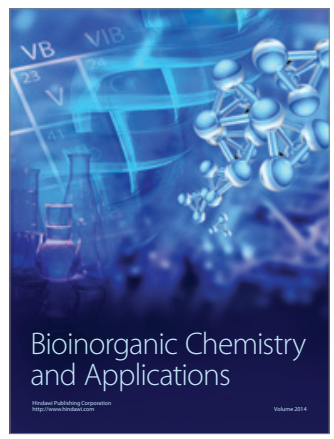

Inorganic Chemistry
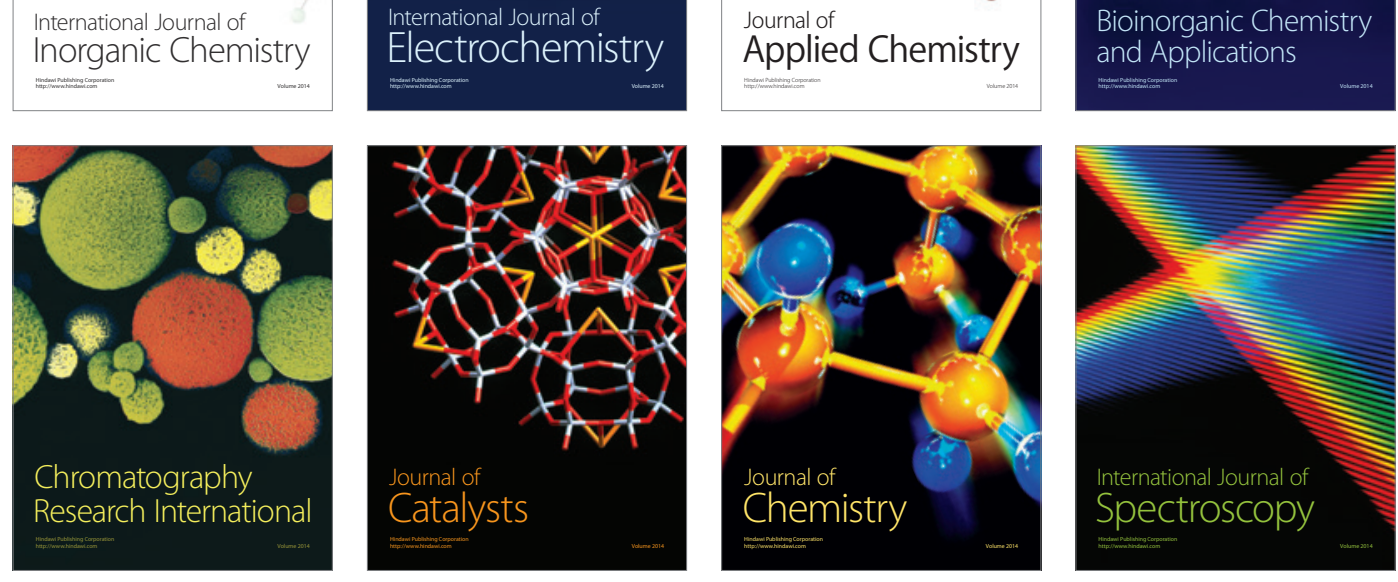